\title{
Synthesis, Anti-inflammatory and Anti-nociceptive Evaluation of Palmitoyl Benzamides
}

\author{
Haruna Baba ${ }^{1 *}$, Cyril O Usifoh ${ }^{2}$ and Patrick O Igbinaduwa ${ }^{2}$ \\ ${ }^{1}$ Department of Pharmaceutical and Medicinal Chemistry, Faculty of Pharmacy, Niger Delta University, Wilberforce Island, \\ Bayelsa State, ${ }^{2}$ Department of Pharmaceutical Chemistry, University of Benin, Benin City, Nigeria \\ *For correspondence: Email: babharun@yahoo.co.uk; Tel: +2347034402435
}

\begin{abstract}
Purpose: To synthesize and characterize palmitoyl amino benzamides, and to evaluate them for possible anti-inflammatory and anti-nociceptive activities.

Methods: Palmitoyl amino benzamides were synthesized by the opening of isatoic anhydride ring with respective amino acids (glycine, $\beta$-alanine and $\gamma$-aminobutyric acid) and the condensation of the product with palmitoyl chloride. The final products were purified on column chromatography, eluting with dichloromethane/ethyl acetate. All the compounds were unequivocally characterized using the combination of infra red (IR), $1 \mathrm{H}$ and $13 \mathrm{C}$ (nuclear magnetic resonance (NMR), mass spectrometry (MS) and elemental analysis. In vivo anti-inflammatory and anti-nociceptive activities of the synthesized compounds at 20,50 and 100 $\mathrm{mg} / \mathrm{kg}$ doses were carried out using carrageenan-induced paw oedema in rat and acetic acid-induced writhing in mice, respectively. Aspirin was used at a dose of $100 \mathrm{mg} / \mathrm{kg}$ as the reference drug.

Results: The compounds were obtained in high yield $(70-90 \%)$ and purity. The anti-inflammatory results showed a poor activity for the compounds except o-palmitoylamino $\mathrm{N}$-carboxyethyl benzamide which produced significant inhibition $(p<0.05)$ at a dose of $50 \mathrm{mg} / \mathrm{kg}(43.8 \%$ oedema inhibition) while the reference drug, aspirin, showed $51.3 \%$ inhibition. The anti-nociceptive study, however, showed good inhibition $(p<0.05)$ of acetic acid-induced writhing, with o-palmitoylamino $N$ carboxymethylbenzamide producing $86.2 \%$ inhibition at $100 \mathrm{mg} / \mathrm{kg}$ dose compared with the reference drug (aspirin) which gave $74.3 \%$ inhibition at $100 \mathrm{mg} / \mathrm{kg}$.

Conclusion: The findings of this study indicate that the synthesized compounds, though displaying poor anti-inflammatory activity, do possess promising anti-nociceptive activity.
\end{abstract}

Keywords: Anti-inflammatory, Analgesic, Benzamide, Palmitoyl, Glycine, $\beta$-Alanine, $\gamma$-Aminobutyric acid, Aspirin

Tropical Journal of Pharmaceutical Research is indexed by Science Citation Index (SciSearch), Scopus, International Pharmaceutical Abstract, Chemical Abstracts, Embase, Index Copernicus, EBSCO, African Index Medicus, JournalSeek, Journal Citation Reports/Science Edition, Directory of Open Access Journals (DOAJ), African Journal Online, Bioline International, Open-J-Gate and Pharmacy Abstracts

\section{INTRODUCTION}

Inflammation is a necessary and beneficial host response to foreign challenge or tissue injury that leads ultimately to the restoration of tissue structure and function [1]. Prolonged inflammation can cease to be a beneficial event and it contributes to the pathogenesis of many disease states. Recent studies have shown that certain lipid mediators might have a crucial role in the resolution of inflammation as endogenous anti-inflammatory mediators [2]. The discovery of anandamide (AEA) created an avenue for the search of other important endogenous fatty acid amides which have been shown to have interesting anti-inflammatory and anti-nociceptive activities [3]. 
The pharmacological activity of these endogenous amides is terminated by fatty acid amide hydrolase (FAAH) [4]. This enzyme is an interesting target for drug discovery; since FAAH inhibitors have been shown to potentiate the pharmacological actions of AEA both in vitro and in vivo [5]. The study by Schmid et al [6] clearly indicates that the ethyl head chain is a target for structure-activity studies. Previous work in this area, usually with arachidonyl- and oleoylacyl chains, has resulted in the identification of several potent FAAH inhibitors [7]. However, this approach has an inherent disadvantage in that some of the compounds are active at cannabinoid receptors. In contrast, little is known about the effect of modification of the ethyl head group in $\mathrm{N}$-palmitoylethanolamine, despite the fact that this compound, which reduces the rate of metabolism of AEA by acting as a competing substrate, is inactive at cannabinoid receptors [8]. There is thus a need to further investigate the effect of substitution of the ethyl head group of $\mathrm{N}$ palmitoylethanolamine upon its ability to interact with FAAH. To this end we have synthesized three analogues of $\mathrm{N}$-palmitoylethanolamine by the aromatic substitution of the ethanolamine moiety and they were screened for antiinflammatory and anti-nociceptive activity in vivo.

\section{EXPERIMENTAL}

\section{Materials}

Glycine, $\beta$-alanine, $\gamma$ - aminobutyric acid (GABA), palmitoylchloride and isatoic anhydride were obtained from Sigma-Aldrich, Germany. Acetylsalicylic acid, triethylamine, 1, 4-dioxan, hydrochloric acid and dichloromethane were obtained from BDH Chemicals Limited, England. Precoated thin layer chromatography (TLC), Silica Gel 60 F254 plates were obtained from Merck Darmstadt, Germany. Kieselgel 60 F254 (70-230 mesh for column chromatography, was obtained from Merck Darmstadt, Germany. Kofler electrothermal melting point apparatus CAT Number 1A 6304 was obtained from England. Buck Scientific Infra Red M500 instrument was obtained from Buck Scientific Inc, Norwalk, Connecticut, USA. Varian Gemini 200 (250MHz) for Nuclear Magnetic Resonance (NMR) characterization was obtained from Varian Inc., Palo Alto, California, USA. Varian MAT 44S mass spectrometer was obtained from Thermo Finnigan, San Jose, California, USA. PerkinElmer $2400 \mathrm{CHN}$ elemental analyzer was obtained from Waltham, Massachusetts USA.

\section{General reaction scheme}

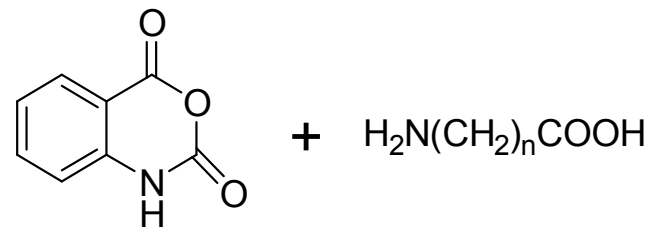

Amino acid

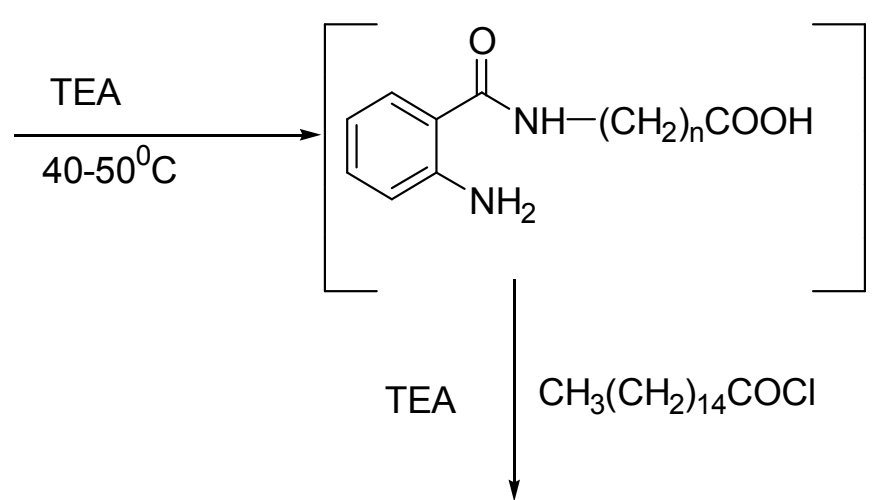<smiles>CCCCCCCCCCC(=O)Nc1ccccc1C(=O)O</smiles>

$$
n=1-3
$$



Preparation of o-palmitoylamino N-carboxy-
methylbenzamide

Isatoic anhydride $(5 \mathrm{~g}, 30.67 \mathrm{mmol})$, glycine (2.3 $\mathrm{g}, 30.67 \mathrm{mmol}$ ) and triethylamime (TEA) (4.25 $\mathrm{ml}, 30.67 \mathrm{mmol}$ ) was mixed in $50 \mathrm{~mL}$ of water and heated at $40-50{ }^{\circ} \mathrm{C}$ in an oil bath for $5 \mathrm{~h}$; TLC analysis revealed the disappearance of starting material at the end of the reaction. The $\mathrm{pH}$ of the mixture was brought to between 3 to 5 with $1 \mathrm{~N} \mathrm{HCl}$. The mixture was then partitioned with ethyl acetate $(3 \times 50 \mathrm{~mL})$, and the solvent removed to give a product which was not isolated. The product (o-aminocarboxymethylbenzamide; $1.793 \mathrm{~g}, 9.24 \mathrm{mmol}$ ) from the above procedure was treated with palmitoylchloride (2.8 $\mathrm{mL}, 9.24 \mathrm{mmol}$ ) in 1, 4-dioxan in the presence of TEA. At the end of the reaction, the mixture was poured into water and exhaustively extracted with ethyl acetate $(3 \times 50 \mathrm{~mL})$. The combined organic fraction was dried over anhydrous $\mathrm{Na}_{2} \mathrm{SO}_{4}$ and evaporated in vacuo to leave behind a crude product which was purified on column chromatography using dichloromethane and then dichloromethane/ethyl acetate (3:1).

\section{Preparation of o-palmitoylamino N-carboxy- ethylbenzamide}

Isatoic anhydride $(5 \mathrm{~g}, 30.67 \mathrm{mmol}), \beta$-alanine $(2.73 \mathrm{~g}, 30.67 \mathrm{mmol})$ and TEA $(4.25 \mathrm{~mL}, 30.67$ mmol) was mixed in $50 \mathrm{~mL}$ of water and stirred at 40-50 ${ }^{\circ} \mathrm{C}$ in an oil bath for $5 \mathrm{~h}$. TLC showed completion of reaction. The mixture was acidified with $1 \mathrm{~N} \mathrm{HCl}\left(\mathrm{pH}_{3}-5\right)$ and partitioned with ethyl acetate $(3 \times 50 \mathrm{ml})$. The combined organic fraction was evaporated in vacuo and the final product $(3.134 \mathrm{~g}, 15.07 \mathrm{mmol})$ was treated with palmitoylchloride $(4.56 \mathrm{~mL}, 15.07 \mathrm{mmol})$ in 1, 4dioxan in the presence of TEA. At the end of the reaction, the mixture was poured into water and exhaustively extracted with ethyl acetate $(3 \times 50$ $\mathrm{mL}$ ). The combined organic fraction was dried over anhydrous $\mathrm{Na}_{2} \mathrm{SO}_{4}$ and evaporated in vacuo to leave behind a crude product which was purified on column chromatography (silica gel 70 - 230 mesh) eluting with dichloromethane and then dichloromethane/ ethylacetate (3:1).

\section{Preparation of o-palmitoylamino N-carboxy- propylbenzamide}

Isatoic anhydride ( $5 \mathrm{~g}, 30.67 \mathrm{mmol})$, GABA (3.16 $\mathrm{g}, 30.67 \mathrm{mmol}$ ) and TEA (4.3 mL) were mixed and stirred in $50 \mathrm{~mL}$ of water for $5 \mathrm{~h}$ at $40-50$ ${ }^{\circ} \mathrm{C}$. TLC showed completion of reaction. The mixture was acidified with $1 \mathrm{~N} \mathrm{HCl}$ to $\mathrm{pH} 3-5$ and extracted with ethyl acetate $(3 \times 50 \mathrm{~mL})$. The combined organic phase was evaporated in vacuo. The final product $(1.643 \mathrm{~g}, 7.4 \mathrm{mmol})$ was treated with palmitoyl chloride $(2.4 \mathrm{ml}, 7.4 \mathrm{mmol})$ in 1, 4-dioxan in the presence of TEA. At the end of the reaction, the mixture was poured into water and exhaustively extracted with ethyl acetate $(3 \times 50 \mathrm{~mL})$. The combined organic fraction was dried over anhydrous $\mathrm{Na}_{2} \mathrm{SO}_{4}$ and evaporated in vacuo to leave behind a crude product, which was purified on column chromatography (silica gel 70 - 230 mesh) eluting with dichloromethane and dichloromethane/ ethyl acetate (3:1).

\section{Animals}

Swiss mice (17- $30 \mathrm{~g})$ and Wistar rats (97- $225 \mathrm{~g}$ ) of either sex purchased from Ambrose Alli University Animal House, Ekpoma, Nigeria were used. The animals were housed in the central animal facility of the Niger Delta University College of Health Sciences (NDUCHS) under the supervision of qualified personnel; with $12 \mathrm{~h}$ dark/12 h light cycles and were fed with grower feeds (Vita Feeds, Ibadan) and water ad libitum. Animals were fasted overnight, with free access to water, prior to experiments. The study was carried out according to the "Principles of Laboratory Animal Care" [9] and approved by the Institutional Animal Ethics Committee of NDU FPMSRCP (Protocol no. NDU CHS/SM-02/2012, Dt. 20.05.12)

\section{Rat paw oedema assay}

Anti-inflammatory activity of the synthesized compounds was evaluated using carrageenaninduced rat paw oedema assay model [10]. The animals were divided into groups (6 rats per group) of both sexes (pregnant females excluded) and were orally administered a dose $(20,50$ and $100 \mathrm{mg} / \mathrm{kg})$ of the test compounds, after an hour carrageenan suspension $(0.1 \mathrm{~mL}, 1$ $\%)$ in saline $(0.9 \% \mathrm{NaCl})$ solution was injected into the sub-plantar area of the right hind paw. The paw thickness was measured hourly over a period of $5 \mathrm{~h}$ with the aid of veneer caliper. Antiinflammatory activity was evaluated by the method of Duffy et al [11] and the percentage inhibition of oedema level by drugs were compared to control as shown in Table 1. Acetyl salicylic acid $(100 \mathrm{mg} / \mathrm{kg})$ was administered orally as positive control while Tween 80 (10\%) used to solubilize the synthesized drugs was used as negative control. Mathematically, antiinflammatory activity was evaluated as in Eq 1.

Activity $=100-\{100 \times(\mathrm{Dt} / \mathrm{C})\}$

where $\mathrm{Dt}$ is the mean value for drug-treated animals and $C$ is the mean value for animals treated without drug (control). 


\section{Evaluation of analgesic activity}

The method of Koster [12] and DiChiacchio [13] were employed. The animals were divided into five groups with 5 mice of both sexes, in each group (pregnant females excluded). The animals were administered a dose $(20,50$ or $100 \mathrm{mg} / \mathrm{kg})$ of the test compounds by gavage. After $1 \mathrm{~h}$, the animals were injected intraperitoneally with 0.2 $\mathrm{ml} / \mathrm{mouse}$ of $0.6 \% \mathrm{v} / \mathrm{v}$ acetic acid solution. Acetic acid-induced writhing were counted and recorded within $20 \mathrm{~min}$. Tween $80(10 \%)$ was used as the negative control while acetylsalicylic acid (100 $\mathrm{mg} / \mathrm{kg}$ p.o) was used as reference drug. The mean of abdominal constrictions for five mice in each group which is an indication of analgesic activity was recorded. Inhibition (\%) of abdominal constrictions of test compounds was compared with control group using the method of Duffy et al [11]. Analgesic activity was computed in terms of inhibition as in Eq 2.

Inhibition $(\%)=100-\{100 \times(\mathrm{Dr} / \mathrm{Cr})\}$

where $\mathrm{Dr}$ is the mean drug response and $\mathrm{Cr}$ is mean control response.

\section{Statistical analysis}

Data obtained were analyzed by Student's t-test and multiple comparisons were done by one-way analysis of variance (ANOVA). A probability level of $<5 \%$ was considered significant $(p<0.05)$.

\section{RESULTS}

\section{Chemistry}

The compounds were obtained in good yield $(70$ - $90 \%$ ) and high purity as shown by the melting point and elemental analysis.

\section{o-Palmitoylamino $\mathrm{N}$-carboxymethylbenzamide}

Yield: $2.84 \mathrm{~g}$ (71\%), Melting point: $96-98{ }^{\circ} \mathrm{C}$. IR (KBr): $3526(\mathrm{OH}), 3025(\mathrm{NH}), 2917(\mathrm{C}-\mathrm{H})$, 2848(CH), 1700(C=O), 1643(C=O), 1586, 1514, $1471 \mathrm{~cm}^{-1}$. 1H NMR (DMSOd 6 ) $\delta: 0.80-0.83(\mathrm{t}, \mathrm{J}=$ $\left.7.5 \mathrm{~Hz}, 3 \mathrm{H}, \mathrm{CH}_{3}\right), 1.01-1.03(\mathrm{~d}, \mathrm{~J}=5.0 \mathrm{~Hz}, 2 \mathrm{H}$, $\left.\mathrm{CH}_{2}\right), 1.21$ (brs, $\left.22 \mathrm{H},\left(\mathrm{CH}_{2}\right)_{11}\right), 1.58$ (brs, $2 \mathrm{H}$, $\left.\mathrm{CH}_{2}\right), 2.27-2.33\left(\mathrm{t}, \mathrm{J}=7.3 \mathrm{~Hz}, 2 \mathrm{H}, \mathrm{CH}_{2}\right), 7.10(\mathrm{~s}$, $1 \mathrm{H}, \operatorname{Ar}-\mathrm{H}), 7.44(\mathrm{~s}, 1 \mathrm{H}, \mathrm{Ar}-\mathrm{H}), 7.67-7.70(\mathrm{~d}, \mathrm{~J}=$ $7.0 \mathrm{~Hz}, 1 \mathrm{H}, \mathrm{Ar}-\mathrm{H}), 8.35-8.38(\mathrm{~d}, \mathrm{~J}=8.3,1 \mathrm{H}, \mathrm{NH})$, $8.77(\mathrm{~s}, 1 \mathrm{H}, \mathrm{NH}), 11.23(\mathrm{~s}, 1 \mathrm{H}, \mathrm{COOH}) .13 \mathrm{C}$ NMR: $14.5,22.3,25.4,28.9,29.2,29.3,29.5$, 29.5, 29.7, 31.6, 31.7, 34.1, 37.9, 120.8 ( $\mathrm{Ar}-\mathrm{C})$, 121.3 ( $\mathrm{Ar}-\mathrm{C}), 122.8(\mathrm{Ar}-\mathrm{C}), 128.44(\mathrm{Ar}-\mathrm{C})$, 132.1 (Ar-C), 139.4 (Ar-C), $168.8(\mathrm{C}=\mathrm{O}), 171.4$ $(\mathrm{C}=\mathrm{O}), 174.9(\mathrm{C}=\mathrm{O})$. MS: $431.4(\mathrm{M}+-1,18 \%)$, 374 (82), 309 (2), 293 (12), 255 (100). Elemental analysis: $\mathrm{C}_{25} \mathrm{H}_{40} \mathrm{~N}_{2} \mathrm{O}_{4}$ (432.615) Found (C: 69.24 , $\mathrm{H}: 9.14, \mathrm{~N}: 6.28$ ), Calculated (C: 69.41, H: 9.32, $\mathrm{N}: 6.48)$

\section{o-Palmitoylamino $\mathrm{N}$-carboxyethylbenzamide}

Yield: $6.56 \mathrm{~g}(97.47 \%)$ Melting point: $102-104{ }^{\circ} \mathrm{C}$ IR (KBr) $3528(\mathrm{OH}), 3028(\mathrm{NH}), 2914(\mathrm{C}-\mathrm{H})$, 2843(CH), 1700(C=O), 1643(C=O), 1586, 1514, $1471 \mathrm{~cm}^{-1} .1 \mathrm{H} \mathrm{NMR}$ (DMSOd6) $\delta: 0.80-0.83(\mathrm{t}, \mathrm{J}$ $\left.=6.8 \mathrm{~Hz}, 3 \mathrm{H}, \mathrm{CH}_{3}\right), 1.02\left(\mathrm{~d}, \mathrm{~J}=6.3 \mathrm{~Hz}, 2 \mathrm{H}, \mathrm{CH}_{2}\right)$, 1.21 (brs, $\left.22 \mathrm{H},\left(\mathrm{CH}_{2}\right)_{11}\right), 1.58$ (brs, $\left.2 \mathrm{H}, \mathrm{CH}_{2}\right), 2.30$ (t, J = 7.3Hz, 2H, CH $)_{2}, 7.09(\mathrm{~s}, 1 \mathrm{H}, \mathrm{Ar}-\mathrm{H}), 7.44$ $(\mathrm{s}, 1 \mathrm{H}, \mathrm{Ar}-\mathrm{H}), 7.67-7.70(\mathrm{~d}, \mathrm{~J}=7.0 \mathrm{~Hz}, 1 \mathrm{H}, \mathrm{Ar}-\mathrm{H})$, 8.35-8.39 (d, J = $8.3 \mathrm{~Hz}, 1 \mathrm{H}, \mathrm{NH}), 8.77(\mathrm{~s}, 1 \mathrm{H}$, $\mathrm{NH}), 11.23$ (s,1H, $\mathrm{COOH}) .13 \mathrm{C}$ NMR: 14.5, 22.3, $25.4,25.9,29.0,29.1,29.2,29.3,29.5,29.5$, 31.7, 34.0, 36.0, 37.9, 120.8 (Ar-C), 121.2 (Ar-C), 122.8 (Ar-C), 128.5 (Ar-C), 132.2 (Ar-C), 139.4 (Ar-C), $168.7(C=O), 171.5(C=0), 173.3(C=O)$. MS: $446(\mathrm{M}+6 \%), 430(6), 358(14), 256(18)$, 250 (34), 222(21), 208(100), 146 (13), 120 (21), 43 (25). Elemental analysis: $\mathrm{C}_{26} \mathrm{H}_{42} \mathrm{~N}_{2} \mathrm{O}_{4}$ (446.642g); Found C: 69.80, H: 9.32, N: 6.04, Calculated C: $69.92, \mathrm{H}: 9.48, \mathrm{~N}: 6.27$

\section{o-Palmitoylamino N-carboxypropylbenzamide}

Yield: $2.50 \mathrm{~g}$ (73.27 \%). Melting point: $98-100{ }^{\circ} \mathrm{C}$ IR (KBr) $3428(\mathrm{OH}), 3228(\mathrm{NH}), 2914(\mathrm{CH}), 2843$ $(\mathrm{CH}), 1700(\mathrm{C}=\mathrm{O}), 1643(\mathrm{C}=\mathrm{O}), 1586,1528 \mathrm{~cm}^{-1}$ 1H NMR $\left(\mathrm{DMSOd}_{6}\right) \delta: 0.75-0.83(\mathrm{t}, \mathrm{J}=7.0 \mathrm{~Hz}$, $\left.3 \mathrm{H}, \mathrm{CH}_{3}\right), 1.14-1.21$ (brs, $\left.22 \mathrm{H}\left(\mathrm{CH}_{2}\right)_{11}\right), 1.57$ (brs, 2H, $\mathrm{CH}_{2}$ ), $1.72-1.77$ (t, J $=7.0 \mathrm{~Hz}, 2 \mathrm{H}$, $\left.\mathrm{CH}_{2}\right), 2.24-2.32\left(\mathrm{~m}, 2 \mathrm{H}, \mathrm{CH}_{2}\right)$ 7.07-7.13 (t, J = $7.8 \mathrm{~Hz}, 1 \mathrm{H}, \mathrm{Ar}-\mathrm{H}), 7.41-7.47(\mathrm{t}, \mathrm{J}=7.5 \mathrm{~Hz}, 1 \mathrm{H}$, Ar-H), 7.67-7.71(d, J = 8.0 Hz, $1 \mathrm{H}$, Ar-H), 8.72 (brt, 1H, N-H), 11.26 (s, 1H, N-H), 12.0 (brs, 1H,O-H) 13C NMR: 14.5, 22.3, 25.4, 28.9, 29.2, 29.3, 29.4, 29.5, 29.7, 31.6, 31.7, 34.1, 37.9, 120.8 (Ar -C), $121.3(\mathrm{Ar}-\mathrm{C}), 122.8(\mathrm{Ar}-\mathrm{C})$, 128.4 (Ar-C), 132.1 (Ar-C), 139.4 (Ar-C), 168.7 $(\mathrm{C}=\mathrm{O}), 171.4(\mathrm{C}=\mathrm{O}), 174.9(\mathrm{C}=\mathrm{O}) . \mathrm{MS}: 461(\mathrm{M}+)$, 264 (10\%), 256 (18), 223 (18), 222 (100), 185 (6), 174 (9), 161 (16), 146 (18), 120 (25), 104 (14). Elemental analysis: $\mathrm{C}_{27} \mathrm{H}_{44} \mathrm{~N}_{2} \mathrm{O}_{4}$ (460.669); Found C: $70.24, \mathrm{H}: 9.42, \mathrm{~N}: 6.02$, Calculated C: 70.59, H: 9.63, N: 6.08)

\section{Pharmacology properties}

The results of the anti-inflammatory activity are shown in Table 1. The percentage oedema inhibition was calculated at the third hour using the formula stated under methods. It was observed that of the three compounds, opalmitoylamino $\mathrm{N}$-carboxyethyl benzamide exhibited the highest dose dependent oedema 
inhibition of $42.4-43.8 \%$ as the dose increased from $20-50 \mathrm{mg} / \mathrm{kg}$ and aspirin the standard drug $(100 \mathrm{mg} / \mathrm{kg}$ ) produced $51.0 \%$ inhibition of oedema when compared to control $(p<0.05)$. As can be seen in Table 2, o-palmitoylamino $\mathrm{N}$ carboxymethylbenzamide $(20,50$ and 100 $\mathrm{mg} / \mathrm{kg}$ ) exhibited the highest dose-dependent anti-nociceptive effect against acetic acidinduced writhing response in mice $(p<0.05)$. oPalmitoylamino $\mathrm{N}$-carboxymethylbenzamide at $100 \mathrm{mg} / \mathrm{kg}$ exhibited $86.2 \%$ inhibition of writhing compared to $74.3 \%$ inhibition of standard drug, aspirin (100 mg/kg).

\section{DISCUSSION}

The in vivo anti-inflammatory activity of the compounds was carried out using carrageenan induced oedema assay, which is a working model of inflammation in the search for new antiinflammatory agents [14]. The oedema which develops in rat paw after the injection of carrageenan in the sub plantar area is a biphasic event [15]. The initial phase (within the first two and half hours) is attributed to the release of histamine and the second phase (from the third hour) is attributed to prostaglandin [16]. The results in Table 1 show that the compounds, except for o-palmitoylamino $\mathrm{N}$-carboxyethyl benzamide have no anti-inflammatory activity. This indicates that aromatic substitution in this class of endogenous compounds destroys their anti-inflammatory activity.

To probe the analgesic activity of test compounds, it was investigated for inhibitory effect on acetic acid-induced abdominal constriction. It has been reported that acetic acid causes an increase in the peritoneal fluid level of prostaglandins $\left(\mathrm{PGE}_{2}\right.$ and $\mathrm{PGF}_{2 \alpha}$ ), involving in part peritoneal receptors [17] and inflammatory pain by inducing capillary permeability. It was proposed by some authors [18] that acetic acid acts indirectly by inducing the release of endogenous mediators, which stimulate the nociceptive neurons. Although the writhing test has poor specificity [19], it is a very sensitive method of screening the anti-nociceptive effects of compounds [18]. The acetic acid-induced writhing reaction in mice is also described as a typical model for inflammatory pain, has long been used as a screening tool for the

Table 1: Effect of palmitoylamino N-carboxybenzamide on carrageenan-induced paw oedema

\begin{tabular}{lccc}
\hline Compound & $\begin{array}{c}\text { Dose } \\
\mathbf{m g} / \mathbf{k g}(\mathbf{p . o .})\end{array}$ & $\begin{array}{c}\text { Change in paw diameter } \\
\text { (Mean } \pm \text { SEM) }\end{array}$ & $\begin{array}{c}\text { \% Oedema inhibition } \\
\text { relative to control at } \\
\text { the } 3^{\text {rd }} \text { hour }\end{array}$ \\
\hline o-Palmitoylamino N- & 20 & $0.810 \pm 0.029$ & 22.8 \\
carboxymethyl & 50 & $0.988 \pm 0.010$ & 5.6 \\
benzamide & 100 & $1.123 \pm 0.021$ & -7.1 \\
o-Palmitoylamino N- & 20 & $0.604 \pm 0.010$ & $42.4^{*}$ \\
carboxyethyl & 50 & $0.589 \pm 0.013$ & $43.8^{*}$ \\
benzamide & 100 & $0.894 \pm 0.015$ & 14.8 \\
o-Palmitoylamino N- & 20 & $1.146 \pm 0.007$ & -9.2 \\
carboxypropyl & 50 & $1.038 \pm 0.026$ & 1.0 \\
benzamide. & 100 & $1.270 \pm 0.025$ & -21.1 \\
Acetylsalicylic acid & 100 & $0.511 \pm 0.028$ & $51.3^{*}$ \\
Control (10 \% Tween 80$)$ & 0.5 mL & $1.049 \pm 0.027$ & - \\
\hline Values are mean \pm S.E.M; ${ }^{*} p<0.05$, compared with control; paired t-test $(n=6) ; p .0$. & $=p e r$ os
\end{tabular}

Table 2: Effect of palmitoylamino $\mathrm{N}$-carboxybenzamide on acetic acid induced writhing in mice

\begin{tabular}{lccc}
\hline Compound & $\begin{array}{c}\text { Dose } \\
\text { (mg/kg, p.o.) }\end{array}$ & $\begin{array}{c}\text { Number of writhing } \\
\text { (Mean } \pm \text { SEM) }\end{array}$ & Inhibition (\%) \\
\hline O-Palmitoylamino N- & 20 & $25.8 \pm 2.3$ & $74.3^{*}$ \\
carboxymethyl & 50 & $15.4 \pm 2.6$ & $84.7^{*}$ \\
benzamide & 100 & $14.8 \pm 4.3$ & $86.2^{*}$ \\
o-Palmitoylamino N- & 20 & $56.8 \pm 4.3$ & 43.6 \\
carboxyethyl & 50 & $47.2 \pm 1.2$ & $53.5^{*}$ \\
benzamide & 100 & $27.4 \pm 1.0$ & $73.3^{*}$ \\
O-Palmitoylamino N- & 20 & $27.8 \pm 1.2$ & $72.3^{*}$ \\
Carboxypropyl & 50 & $25.8 \pm 4.5$ & $74.3^{*}$ \\
benzamide & 100 & $26.0 \pm 1.4$ & $74.3^{*}$ \\
Aspirin & 100 & $25.8 \pm 1.2$ & $74.3^{*}$ \\
Control (10\% Tween 80) & $0.2 \mathrm{~mL}$ & $100.4 \pm 14.7$ & - \\
\hline
\end{tabular}

Values are mean \pm S.E.M; * $p<0.05$, compared with control; paired t-test $(n=6) ;$ p.o. $=$ per os 
assessment of analgesic or anti-inflammatory properties of new agents [19]. At the cellular level, protons depolarize sensory neurons by directly activating a non-selective cationic channel localized on cutaneous, visceral and other types of nocisponsive peripheral afferent C-fibers [20]. The results reported here indicate that oral administration of test compounds produced marked and dose-related antinociception when assessed in acetic acidinduced visceral nociception than antiinflammatory response when induced by carrageenan-induced inflammation.

\section{CONCLUSION}

The findings of the present study demonstrate that the synthesized compounds, namely, palmitoyl benzamides, though showing poor antiinflammatory activity, demonstrated promising anti-nociceptive activity. o-Palmitoylamino Ncarboxymethyl benzamide exhibited the highest anti-nociceptive activity, greater than even the reference drug (aspirin). Thus, there is need for further studies on the compounds for their analgesic activity.

\section{ACKNOWLEDGEMENT}

The authors acknowledge Professor GKE Scriba and Frau Martina Hense of the University of Jena, Germany for assistance with nuclear magnetic resonance and mass spectrometry experiments. Dr LL Nwidu of the Department of Pharmacology and Toxicology, Niger Delta University, Wilberforce Island, Nigeria is also acknowledged for assisting during the animal experiments.

\section{REFERENCES}

1. Florey HW. General pathology. Lloyd-Luke, London, 1970.

2. Serhan CN. Resolution Phase of Inflammation: Novel Endogenous Anti-Inflammatory and Proresolving Lipid Mediators and Pathways. Annu Rev Immunol, 2007, 25: 101-113.

3. Devane WA, Hanus L, Breuer A, Pertwee RG, Stevenson $L A$, Griffin G. Isolation and Structure of a Brain Costituent That Binds to the Cannabinoid Receptor. Science 1992; 258: 1946-1949.

4. Deutch DG, Chin SA. Enzymatic Synthesis and Degradation of Anandamide, a Cannabinoid Receptor Agonist. Biochem. Pharmacol. 1993; 46:791-796.
5. Childers SR, Sexton T, Roy MB. Effects of Anandamide on Cannabinoid Receptors in Rat Brain Membranes. Biochem. Pharmacol. 1994; 47: 711-715.

6. Schmid PC, Zuzarte-Augustin ML, Schmid $\mathrm{HH}$. Properties of Rat Liver N-Acylethanolamine Amidohydrolase. J. Biol. Chem. 1985; 260: 1414514149.

7. Bisogno T, Melck D, De Petrocellis L, Bobrov MY, Gretskaya NM, Bezuglov VV,et al. Arachidinoylserotonin and Other Novel Inhibitors of Fatty Acid Amide Hydrolase. Biochem. Biophys. Res. Commun. 1998; 248: 515-522.

8. Bisogno T, Maurelli, S, Melck D, De Petrocellis L, Di Marzo V. Biosynthesis. Uptake, and Degradation of Anandamide and Palmitoylethanolamide in Leukocytes. J. Biol. Chem. 1997; 272: 3315-3323.

9. World Health Organization (WHO). Principles of laboratory animal care. Chronicle 1985; 39: 51-56.

10. Winter CA, Risley EA, Nuss GW. Anti-inflammatory and anti-pyretic activities of indomethacin, 1- (pChlorobenzyl) -5-methoxy-2-methylindole 3-acetic acid. J. Pharmacol. Exp. Ther. 1963; 141:369.

11. Duffy JC, Dearden JC, Rostron C. Design, synthesis and biological testing of a novel series of antiinflammatory drugs. J. Pharm Pharmacol. 2001; 53: $1505-1514$.

12. Koster R, Anderson M, Debeer EJ. Acetic acid analgesic screening. Fed. Proc. 1959; 18: 418-420.

13. DiChiacchio A, Rimoli MG, Avallone L, Arena $F$, Abignente E, Filippelli $W$ 2-Phenylimidazo[1,2a]pyridine-3-carboxylic Acid Derivatives: Synthesis and Antiinflammatory Activity . Arch. Pharm. Pharm. Med. Chem. 1998; 331: 273.

14. Manueli VEF, Diaz G, Gonzalez A, and Bermejo J. Antinociceptive, anti-inflammatory and antipyretic effects of Lapidin, a bicyclic sesquiterpene. Planta Medica, 1994; 60: 395-399.

15. Vinegar R, Schreiber W, Hugo R. Biphasic development of carrageenan oedema in rats. $J$ Pharmacol. Exp. Ther. 1969; 166: 96-100.

16. DiRosa M, Willoughby DA. Screens for anti-inflammatory drugs. J. Pharm Pharmacol. 1971; 23: 297-298.

17. Deraedt $R$, Jougney $S$, Delevalcee F, Falhout M. Release of prostaglandin $E$ and $F$ in an algogenic reaction and its inhibition. Eur J Pharmacol. 1980; 51: 17-24.

18. Collier HOJ, Dinneen LC, Johnson CA, Schneider C. The abdominal constriction response and its suppression by analgesic drug in the mouse. $\mathrm{Br} J$ Pharmacol 1968, 32: 295-310.

19. Le Bars D, Gozariu M, Cadden S. Animal models of nociception. Pharmacol Rev 2001; 53: 597-652.

20. Reeh PW, Kress M. Molecular physiology of proton transduction nociceptors. Curr Opin Pharmacol 2001; 1: 45-51. 